\title{
Histopathologic Evaluation of the Phyllodes Tumor
}

\author{
Lokot Donna Lubis \\ Histology Department, UniversitySumatera Utara, Indonesia \\ 2lokdonlubegmail.com
}

\begin{abstract}
Phyllodes tumor is a group of tumors with spesific histopathologic features. The characteristic feature is a double layered epithelial component arranged in clefts surrounded by an overgrowing hypercellular mesenchymal components typically organized in leaf-like structures. Adjunctions subclassifications as benign, borderline or malignant must be used when diagnosing a phyllodes tumor. The subclassifications differences were based on its histological characteristics and had been used to predict the biologic behaviour of the tumor. There are difficulties in diagnosing phyllodes tumor due to morphological resemblance with fibroadenomas and problems related to various stromal and glandular epithelium variations. Method. This is a descriptive study. Twenty-five slides and paraffin block from phyllodes tumor patients available at Departement of Anatomical Pathology Medical Faculty University of Sumatera Utara and Haji Adam Malik Hospital Medan were included in this study. The patients characteristics and histopathological features were evaluated using the hematoxilin-eosin slides. Results. A total of 25 women were diagnosed with phyllodes tumor during the study period. Their ages ranged from 20 to 59 years and $60 \%$ of them are over than 40 years. Histologic classification revealed $92 \%$ benign, $8 \%$ borderline and no malignant tumors. Majority benign and all borderline phyllodes tumors exhibit an enhanced intracanalicular growth pattern with leaf-like projections into dilated lumens. Majority of the tumors also exhibit myxoid degeneration. Conclusions. Histologic classification revealed benign tumors found in majority patients. Several histologic features such as an enhanced intracanalicular growth pattern and myxoid degeneration found in majority case.
\end{abstract}

Keywords - Phyllodes tumor, clinical features, histopathologic features, grade, stromal variations.

\section{INTRODUCTION}

Breast fibroepithelial lesions are a heterogenous group of neoplasms with biphasic elements. The biphasic elements consist of proliferation of both epithelial and stromal components [1]. Fibroadenoma and phyllodes tumor (PT) are the majority types [2]. The classification of these various entities into a single category were based on their similarities in morphology and clinical appearances [3].

PTs have a dramatic clinical presentations and an aggresive histological appearances and draw more attentions inspite of majority lesions are benign [3] This tumor was initially described in 1774 but fully described in 1838 by Johannes Müller [4], [5], [6]. The term cystosarcoma phyllodes was used to underline the leaf-like pattern and fleshy macroscopic appearance of the tumors [5] [7]. Phyllodes tumor was the currently widely used and the preferred nomenclature by WHO [2]. PT is a group of generally circumscribed fibroepithelial neoplasms, microscopically resembling intracanalicular fibroadenomas, characterized by a double-layered epithelial components arranged in clefts surrounded by overgrowing hypercellular mesenchymal components typically organized in leaf-like structures [2]. Adjunctions sub classifications as benign, borderline or malignant must be used when diagnosing a PT. The subclassifications differences were based on its histological characteristics and had been used to predict the biologic behaviour of the tumor [5], [8]. Although histologic characteristics have been useful in predicting biologic behavior, specific parameters that can define the likelihood for recurrence are not fully accepted [9]. There are difficulties in diagnosing phyllodes tumor due to morphological resemblance with fibroadenomas and problems related to various stromal and glandular epithelium variations.

\section{MATERIAL AND METHOD}

\section{A. Sample and Data Collection}

This is a descriptive study with cross sectional approach. The study conducted in Departement of Anatomical Pathology Medical Faculty University of Sumatera Utara for 6 months. Twenty five slides and paraffin block from phyllodes tumor patients diagnosed between January 2010 and December 2011 available at Departement of Anatomical Pathology Medical Faculty University of Sumatera Utara and Haji Adam Malik Hospital Medan were included in this study. The parameters were patients characteristics and histopathological features of the 
PT. Patient details were obtained from medical record.

\section{B. Tumors Data Collection}

Tumor size and macroscopic findings of hemorrhage, myxoid, and of necrotic changes were gained from surgical pathology reports. Histologic slides were retrieved and reviewed by two pathologists. PT were diagnosed when the tumor have prominent fronds or leaf-like pattern and increased stromal cellularity [2].

Classification into benign, borderline, and malignant subclassifications based on the histologic features by WHO [2]. The histologic features we used to subclassify PT were the degree of stromal hypercellularity, cytologic atypia, mitotic activity, stromal overgrowth, and the borders status (circumscribed vs permeative). A well-defined border was characterized by a pushing margin that protruded against the surrounding breast tissue; a permeative border was characterized by tumor invation into adjacent tissue without a well-defined interface between tumor and nonlesional tissue. Stromal hypercellularity and cytologic atypia were categorized as mild, moderate, or severe. Stromal mitotic activity was quantified per 10 high-power fields (hpf) of the microscope objective (10x eyepiece and $40 \times$ objective) in the most mitotically active areas of the stroma. ${ }^{2}$ Stromal overgrowth, defined as a low-power field (10x eyepiece and $4 \times$ microscope objective) that consist of stroma without epithelial elements present.

The histologic features to diagnose a benign PT were well-defined margins, mild stromal hypercellularity, none or mild stromal cytologic atypia, few mitoses $(<5 / 10 \mathrm{hpf})$, and absent stromal overgrowth. A malignant PT was diagnosed when the lesion showed a marked and diffuse stromal hypercellularity, marked cytologic atypia, presence of stromal overgrowth, abundant mitotic activity ( $\geq 10 / 10 \mathrm{hpf}$ ), and permeative margins; A malignant PT also diagnosed in the presence of a malignant heterologous element without requirement for other histological criteria. Borderline PT showed some but not all characteristics found in malignant PT. The histologic characteristics to diagnose a borderline PT were well-defined or focally permeative margins, moderate stromal hypercellularity, mild or moderate stromal cytologic atypia, frequent mitoses (5-9/10 hpf), and absent or very focal stromal overgrowth.

Other histologic features such as the presence of epithelial hyperplasia (mild, moderate, or severe), the presence or absence of epithelial metaplasia, and pseudoangiomatous stromal hyperplasia (PASH) within the tumor were evaluated. The PASH presence determined by slit-like spaces within the PT stroma at least 1 low-power field. To make a distinction of malignant PT from metaplastic carcinoma, the observation must find the presence of heterologous stromal elements, with typical phyllodes tumor areas together with absence of a malignant epithelial component.

\section{RESULTS}

\section{A. Sample Characteristics}

A total of 25 women were diagnosed with phyllodes tumor during the study period. Their ages ranged from 20 to 59 years and $60 \%$ of them are over than 40 years. The patients categorized by their age into age group of younger than 25 years, 26 to 39 years and 40 years revealed the following: $1(4 \%), 8(36 \%)$ and $16(60 \%)$ respectively. We were unable to evaluate the ethnic distribution due to lack of data in the medical records.

TABLE I

AGE DISTRIBUTION

\begin{tabular}{|c|c|c|}
\hline Age & Frequency $(\mathbf{n})$ & Percentage $\mathbf{( \% )}$ \\
\hline$<25$ years & 1 & 4 \\
\hline 26-39 years & 8 & 36 \\
\hline$>40$ years & 16 & 60 \\
\hline Total & 25 & 100 \\
\hline
\end{tabular}

\section{B. Pathologic Findings}

Majority of the case did not report the location of the PT (84\%) and only 4 cases $(16 \%)$ enclosed the location. Evaluation of the surgical procedures revealed $10(40 \%)$ women underwent excisional biopsy and $15(60 \%)$ underwent mastectomy.

TABLE II

LOCATION AND SURGICAL PROCEDURE DISTRIBUTION

\begin{tabular}{|c|c|c|}
\hline $\begin{array}{c}\text { Location and Surgical } \\
\text { Procedure }\end{array}$ & Frequency & $\begin{array}{c}\text { Percentage } \\
(\boldsymbol{\%})\end{array}$ \\
\hline $\begin{array}{c}\text { Location information: }(\mathrm{n}=25) \\
\text { - Right Breast }\end{array}$ & 4 & 16 \\
\hline
\end{tabular}




\begin{tabular}{|c|c|c|}
\hline $\begin{array}{c}\text { Location and Surgical } \\
\text { Procedure }\end{array}$ & Frequency & $\begin{array}{c}\text { Percentage } \\
(\boldsymbol{\%})\end{array}$ \\
\hline$\bullet \quad$ Left Breast & 1 & \\
$\bullet \quad$ Not Mentioned & 21 & 84 \\
\hline Surgical Procedure: $(\mathrm{n}=25)$ & & \\
$\bullet \quad$ Excisional biopsy & 10 & 40 \\
- Mastectomy & 15 & 60 \\
\hline
\end{tabular}

Histologic classification revealed $92 \%$ of cases were benign $\mathrm{PT}, 8 \%$ borderline PT and no malignant tumors. Two cases of borderline PT were diagnosed in age group 26-39 years. Majority of patients aged over than 40 years and all of them had been diagnosed with benign PT.

TABLE III

CLINICAL DATA AND MACROSCOPIC FINDINGS CORRELATED WITH HISTOLOGIC GRADE

\begin{tabular}{|c|c|c|c|c|c|}
\hline Feature & \multicolumn{2}{|c|}{$\begin{array}{l}\text { Benign } \\
\text { Frequency } \\
\quad(\%)\end{array}$} & \multicolumn{2}{|c|}{$\begin{array}{l}\text { Borderline } \\
\text { Frequency } \\
\quad(\%)\end{array}$} & $\begin{array}{l}\text { Maligant } \\
\text { Frequenc } \\
\mathbf{y}\end{array}$ \\
\hline $\begin{array}{l}\text { Patients } \\
\text { Distribution }\end{array}$ & 23 & (92) & 2 & (8) & 0 \\
\hline $\begin{array}{l}\text { Age Group: } \\
\text { - }<25 \text { years }(n=1) \\
\text { - } 26-39 \text { years }(n=8) \\
\text { - }>40 \text { years }(n=16)\end{array}$ & $\begin{array}{c}1 \\
6 \\
16\end{array}$ & $\begin{array}{r}(100) \\
(80) \\
(100)\end{array}$ & $\begin{array}{l}0 \\
2 \\
0\end{array}$ & $\begin{array}{l}(0) \\
(20) \\
(0)\end{array}$ & $\begin{array}{l}0 \\
0 \\
0\end{array}$ \\
\hline $\begin{array}{l}\text { Surgical Procedure: } \\
\text { - Excisional biopsy } \\
(\mathrm{n}=10) \\
\text { - Mastectomy } \\
(\mathrm{n}=15)\end{array}$ & 13 & $\begin{array}{l}(100) \\
(87)\end{array}$ & 2 & $\begin{array}{c}(0) \\
(13)\end{array}$ & $\begin{array}{l}0 \\
0\end{array}$ \\
\hline $\begin{array}{l}\text { Tumor size in } \\
\text { mastectomy } \\
\text { tissues: }(\mathrm{n}=15) \\
\text { - Size } 5-10 \mathrm{~cm} \\
\text { - Not Mentioned }\end{array}$ & $\begin{array}{c}2 \\
11\end{array}$ & $\begin{array}{l}(13,3) \\
(73,3)\end{array}$ & $\begin{array}{l}0 \\
2\end{array}$ & $\begin{array}{c}(0) \\
(13,3)\end{array}$ & $\begin{array}{l}0 \\
0\end{array}$ \\
\hline $\begin{array}{l}\text { Tumor margin in } \\
\text { mastectomy } \\
\text { tissues: }(\mathrm{n}=15) \\
\text { - Poorly } \\
\text { circumscribed } \\
\text { - Not Mentioned }\end{array}$ & 11 & $\begin{array}{l}(13,3) \\
(73,3)\end{array}$ & 2 & $\begin{array}{c}(0) \\
(13,3)\end{array}$ & $\begin{array}{l}0 \\
0\end{array}$ \\
\hline
\end{tabular}

Only two cases $(13,3 \%)$ dictated the tumor size on the gross description of mastectomy specimen. Gross description categorized two cases $(13,3 \%)$ as poorly circumscribed. The size and the nature of the tumor borders were not documented or not available in the surgical pathology reports for the remaining 11 cases $(73,3 \%)$.
TABLE IV

HISTOLOGIC FEATURES CORRELATED WITH HISTOLOGIC GRADE

\begin{tabular}{|c|c|c|c|c|}
\hline Histologic Features & $\begin{array}{r}\mathbf{I} \\
\text { Freq }\end{array}$ & $y,(\%)$ & $\begin{array}{r}B \\
\text { Frec }\end{array}$ & $\begin{array}{l}\text { line } \\
\mathrm{y},(\%)\end{array}$ \\
\hline $\begin{array}{l}\text { Leaf-like pattern: } \\
\text { - } \quad \text { Present }(n=16) \\
\text { - } \quad \text { Absent }(n=9)\end{array}$ & $\begin{array}{c}14 \\
9\end{array}$ & $\begin{array}{c}(87,5) \\
(100)\end{array}$ & $\begin{array}{l}2 \\
0\end{array}$ & $(12,5)$ \\
\hline $\begin{array}{l}\text { Stromal } \\
\text { Hypercellularity: } \\
\text { - } \quad \text { Mild }(n=15) \\
\text { - } \quad \text { Moderate }(n=9) \\
\text { - } \quad \text { Severe }(n=1)\end{array}$ & $\begin{array}{c}15 \\
8 \\
0\end{array}$ & $\begin{array}{c}(100) \\
(89) \\
0\end{array}$ & $\begin{array}{l}0 \\
1 \\
1\end{array}$ & $\begin{array}{c}0 \\
(11) \\
(100)\end{array}$ \\
\hline $\begin{array}{ll}\text { Stromal cell } \\
\text { pleomorphism: } \\
\text { - } \quad \text { Mild }(n=21) \\
\text { - } \quad \text { Moderate }(n=3) \\
\text { - } \quad \text { Severe }(n=3)\end{array}$ & $\begin{array}{c}21 \\
2 \\
0\end{array}$ & $\begin{array}{c}(100) \\
(67) \\
0\end{array}$ & $\begin{array}{l}0 \\
1 \\
1\end{array}$ & $\begin{array}{c}0 \\
(33) \\
(100)\end{array}$ \\
\hline $\begin{array}{l}\text { Mitotic Activity: } \\
\text { - } \quad<5 / \mathrm{HPF}(\mathrm{n}=23) \\
-\quad 5-10 / \mathrm{HPF}(\mathrm{n}=2)\end{array}$ & $\begin{array}{c}23 \\
0\end{array}$ & $\begin{array}{c}(100) \\
0\end{array}$ & $\begin{array}{l}0 \\
2\end{array}$ & $\begin{array}{c}0 \\
(100)\end{array}$ \\
\hline $\begin{array}{l}\text { Microscopic myxoid } \\
\text { change: } \\
\text { - Present }(n=20) \\
\text { - Absent }(n=5)\end{array}$ & $\begin{array}{c}18 \\
5\end{array}$ & $\begin{array}{c}(90) \\
(100)\end{array}$ & $\begin{array}{l}2 \\
0\end{array}$ & (10) \\
\hline $\begin{array}{l}\text { Pseudoangiomatous } \\
\text { stromal hyperplasia }\end{array}$ & 0 & 0 & 0 & 0 \\
\hline $\begin{array}{l}\text { Stromal } \\
\text { Multinucleated giant } \\
\text { Cell } \\
\text { - Present }(n=1) \\
\text { - Absent }(n=24)\end{array}$ & $\begin{array}{c}1 \\
22\end{array}$ & $\begin{array}{l}(100) \\
(92)\end{array}$ & $\begin{array}{l}0 \\
2\end{array}$ & $\begin{array}{c}0 \\
(8)\end{array}$ \\
\hline Stromal metaplasia & 0 & 0 & 0 & 0 \\
\hline $\begin{array}{l}\text { Microscopic } \\
\text { hemorrhage } \\
\text { - } \quad \text { Present }(n=15) \\
\text { - } \quad \text { Absent }(n=10)\end{array}$ & $\begin{array}{c}14 \\
9\end{array}$ & $\begin{array}{l}(93) \\
(90)\end{array}$ & $\begin{array}{l}1 \\
1\end{array}$ & $\begin{array}{l}(7) \\
(10)\end{array}$ \\
\hline Epithelial metaplasia & 0 & 0 & 0 & 0 \\
\hline $\begin{array}{l}\text { Epithelial hyperplasia } \\
\text { - } \quad \text { Present }(n=3) \\
\text { - } \quad \text { Absent }(n=22) \\
\end{array}$ & $\begin{array}{c}3 \\
20 \\
\end{array}$ & $\begin{array}{c}(100) \\
(90)\end{array}$ & $\begin{array}{l}0 \\
2 \\
\end{array}$ & $\begin{array}{c}0 \\
(10) \\
\end{array}$ \\
\hline Epithelial malignancy & 0 & 0 & 0 & 0 \\
\hline
\end{tabular}

Many lesions showed histologic variability and definitive phyllodes features occasionally were focal within the tumors. All tumors have prominent fronds or leaf-like pattern and increased stromal cellularity. Mitotic activity ranged from zero to 8 mitosis per $10 \mathrm{HPF}$. Mitotic activity > 5/HPF was found on two cases of borderline PT. There was one case with stromal multinucleated giant cells, numbering from 1 to 2 such cells per $10 \mathrm{HPF}$ in benign PT. These cells were scattered in the most hypercellular area.

Microscopic myxoid change were observed in all PT cases (90\% in benign PT, $10 \%$ in borderline PT). 
Microscopic hemorrhage found in $93 \%$ benign PT and $7 \%$ borderline PT. Neither PASH or stromal metaplasia or heterologues components found in all cases.

There were 3 cases of benign PT with epithelial hyperplasia. Mild epithelial hyperplasia was diagnosed in two cases and adenosis in one case. There was no hyperplasia in the epithelial elements of the borderline PT. Majority benign and all borderline phyllodes tumors exhibit an enhanced intracanalicular growth pattern with leaf-like projections into dilated lumens. Epithelial elements malignancy was absent in all lesions.

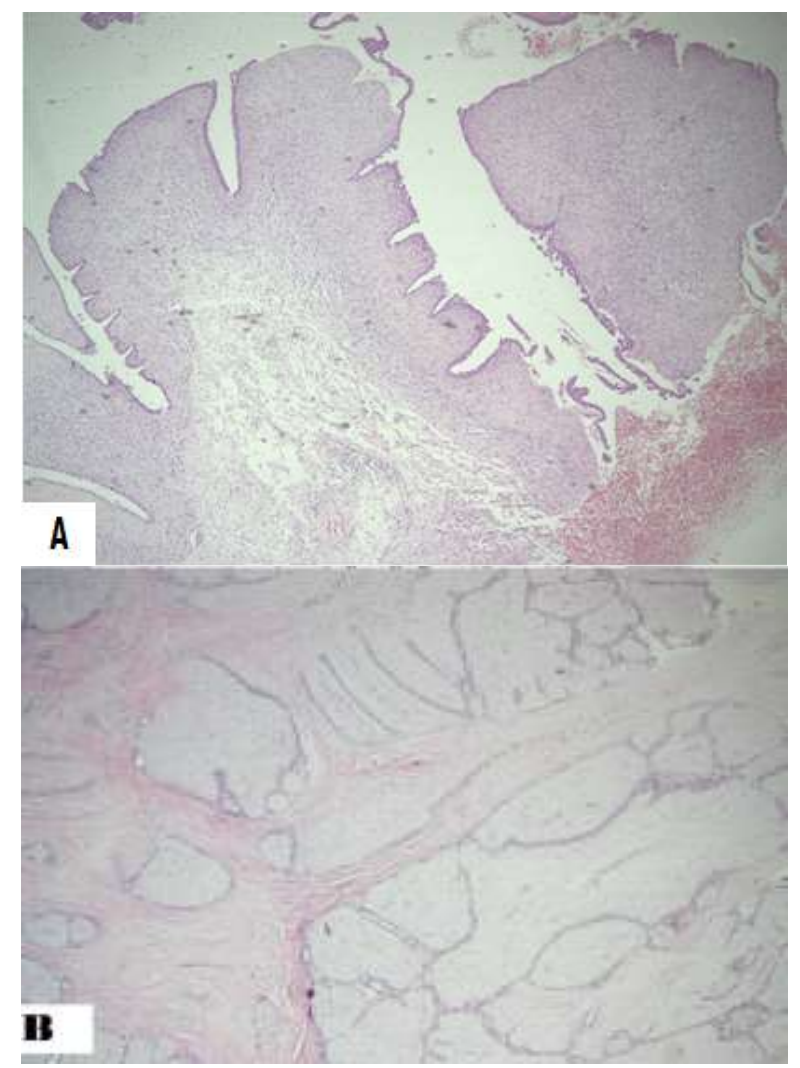

Fig. 1. Histopathologic Features of Benign Phyllodes Tumor.

Fig.1 Show A and B. Stromal proliferation creating a leaf-like structures with myxoid area and hemorrhagic area. (Hematoksilin and Eosin $40 \mathrm{x}$ ).
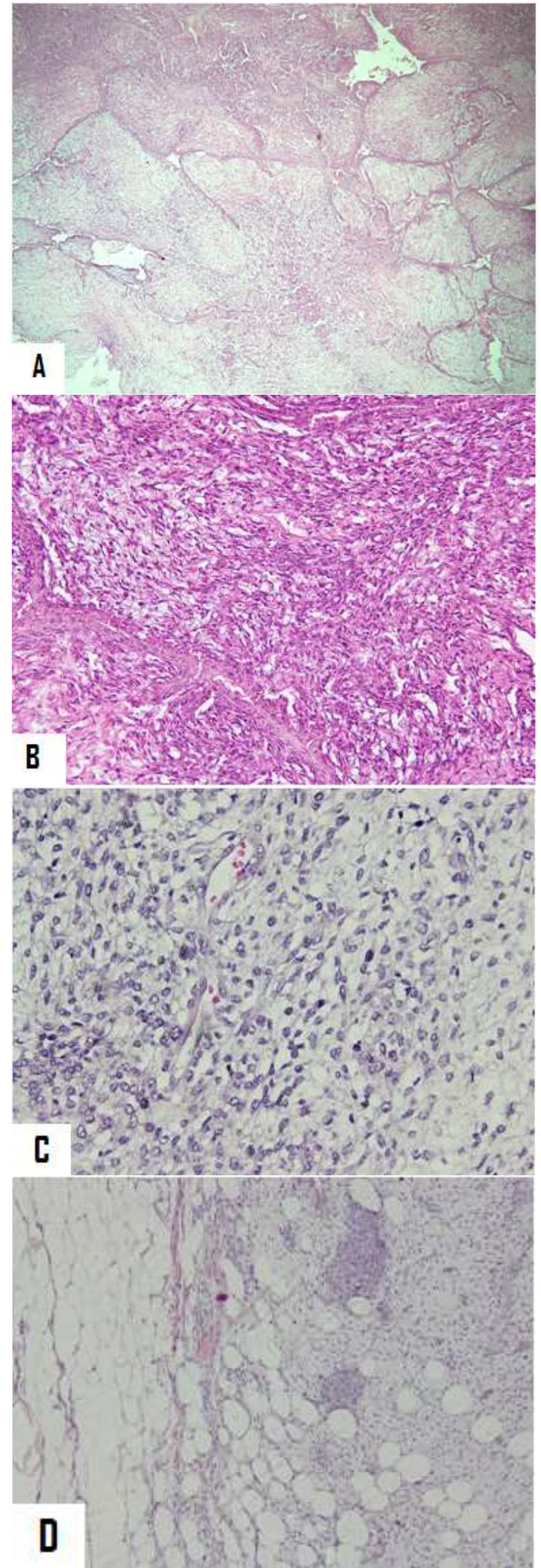

Fig. 2. Histopathologic Features of Borderline Phyllodes Tumor. 
Fig. 2. Show A and B. Stromal proliferation creating a leaf-like structures with moderate cellularity. (A. Hematoksilin Eosin $40 \mathrm{x}, \mathrm{B}$. Hematoksilin Eosin 200x).

C mesenchymal components with moderate cellularity and moderate nuclear pleomorphism. (Hematoksilin Eosin $400 \mathrm{x}$ )

D Permeative border into adipose tissue. (Hematoksilin Eosin $100 \mathrm{x}$ )

\section{IV.DISCUSSION}

PT are relatively uncommon neoplasms than fibroadenoma [1], [10]. and the incidence is uncertain [1]. PT belong to fibroepithelial lesions of the breast and representing $0,3-1 \%$ of primry breat neoplasms and $2,5 \%$ of all fibroepithelial lesions [3], [11]. PT predominantly found in fifth decade and uncommon in young age [3]. The age interval is between 10-86 years [5]. During our study, we observed that majority patients were over than 40 years (age interval 20-59 years). Other study also indicate PT predominantly occur in 40-50 year old women [1], [2]. Our study also revealed $4 \%$ of PT cases found in $<25$ years group. This finding indicate that the PT diagnosis cannot be excluded on the basis of age [6].

Patients came with unilateral painless, firm lump and free from the overlying skin [2], [5], [12]. PT usually occur as solitery unilateral lump [5]. PT rarely presents as a multifocal lesions in single breast or both breast [2], [5]. In our study the tumor was sent without location information therefore we are unable to analayze.

In other study, PT reported measures from few centimeters to more than 20 centimeters [3]. Larger tumor than $4 \mathrm{cms}$ or a histrory of rapid growth, indicate a PT [6]. During our study, we observed 15 cases of mastectomy specimens and only 2 cases enclosed the tumor size, therefore we are unable to analayze.

Grossly, PT appear as solid, relatively well demarcated, lobulated mass or with pushing border [2], [3]. Our study revealed from 15 cases of mastectomy specimens, only 2 cases enclosed the margin status. Other macroscopic informations that were useful in PT diagnosis such as the cleft-like spaces or leaf-like pattern [2], unencapsulated, single or multinodular [5], the presence of necrosis, cystic degeneration, and hemorrhagic area [2], [3], flattened nipple and involvement of the overlying skin [6], were not documented in surgical pathology reports.

Although an accepted criteria to classify PT based on its histological features, the aplication of this criteria is not fully objective [9]. During our study, we observed histologic variability and definitive phyllodes features occasionally were focal within the tumors. All tumors have prominent fronds or leaf-like pattern and increased stromal cellularity. Stromal cellularity is often varied on PT with focal areas similar to fibroadenoma but differ sharply on more sellular area [5]. Stromal and cellular variability created diagnostic problems in fine needle aspiration or core needle specimens [5], [6]. To properly determine the PT grade, an excisional biopsy is required [5].

Other study revealed that majority of PT $(60 \%)$ are benign and only $20 \%$ are malignant PT [3]. In this study, we documented $92 \%$ benign PT and only $8 \%$ of borderline PT. Two cases of borderline PT were diagnosed in age group 26-39 years. Majority of patients aged over than 40 years and all of them had been diagnosed with benign PT. It is imperative to differ benign from borderline PT. Benign PT do not metastasize, with lesser risk for local recurrence, longer interval to recurrence and, most importantly almost all initial local recurrences are histologically benign. Borderline PTs tend to have earlier local recurrences, with histologically high grade recurrences [5].

Overgrowing hypercellular mesenchymal components typically organized in leaf-like structures was the histological characteristic features of PT [3]. In this study, the over growing hypercellular stomal components were found in majority of benign PT and in all borderline PT. Stromal expansion and cellularity are typically uniform throughout the lesion, but can be heterogeneous as well [5].

Both stroma of fibroadenoma and PT may exibit microscopic myxoid change. This change tend to homogenously distributed in fibroadenoma but localize and undergo degenerative changes in PT. Pseudoangiomatous stromal hyperplasia were found in PT cases and in some cases maybe prominent histological findings. Rarely multinucleated stromal 
giant cell found in PT with PASH stroma. This cells indicated a lymphophagositosis activity [5].

Mitotic activity varied from zero to 8 mitosis per 10 HPF. There was one case with stromal multinucleated giant cells, numbering from 1 to 2 such cells per $10 \mathrm{HPF}$ in benign PT. These cells were scattered in the most hypercellular area. No PASH and stromal metaplasia found in this study. Majority of cases (90\%), showed myxoid degeneration. Microscopic hemorrhage were found in benign and borderline PT. In benign PT, mitotic activity is very few if any mitoses. Most benign tumors have modest to marked cellular overgrowth with slight to moderate cytologic pleomorphism[5].

PT may accompanied by epithelial hyperplasia. The hyperplasia often appear as variable thickness of the columnar or cuboidal epithelial lining the slit-like spaces that may progress focally or diffusely to papillary or cribriform hyperplasia. Lobules may be involved in PT development and appear as proliferative change in sclerosing adenosis [5]. In this study, we documented 3 cases with mild epithelial hyperplasia and one case with adenosis. Neither epithelial metaplasia and epithelial malignancy were found. Other study found "marked epithelial hyperplasia" in one-third of benign PTs, including four (13\%) with atypia, and in $26 \%$ of malignant PT [5].

\section{CONCLUSIONS}

We observed histologic variability and definitive phyllodes features occasionally were focal within the tumors. Histologic classification revealed benign tumors found in majority patients. Several histologic features such as an enhanced intracanalicular growth pattern and myxoid degeneration found in majority case. Undocumented clinicopathological data correlated to diagnostic difficulties.

\section{REFERENCES}

[1] Tse GMK, Tan PH. Recent advances in the pathology of fibroepithelial tumours of the breast. Current Diagnostic Pathology. 2005; 11: 426-34. Available at: http://www.upmamaria.net/caso_del mes/2010/12 Diciembre2010/Recent $\% 20$ advances $\% 20$ in $\% 20$ the $\% 20$ pathology $\% 20$ of $\% 20$ fibro epithelial\%20tumours\%20of\%20the\%20breast.pdf

[2] Tan PH, Tse G, Lee A, Simpson JF, Hard AM. The WHO classification of tumours; Pathology and genetics of tumours of breast and female genital organs. In: Fibroepithelial tumours. Lakhani SR, Ellis IO, Schnitt SJ, Tan PH, van de Vijver, editor. France: IARC Press; 2014

[3] Pinder SE, Mulligan AM, O’Malley FP. Breast pathology. In Fibroepithelial Lesions, Including Fibroadenoma and Phyllodes Tumors. Second edition. Philadelphia: Elsevier Saunders; 2011.

[4] Mansel RE, Webster DJT, Sweetland HM. Benign disorders and disease of the breast. In: Fibroadenoma related tumours. Third edition. Saunders Elsevier; 2009.

[5] Rosen PP. Rosen's breast pathology. In: Fibroepithelial neoplasms. Third edition. Lippincott Williams \& Wilkins; 2009.

[6] Rosai J. Rosai and Ackerman Surgical Pathology. 10th edition. Mosby Elsevier; 2011.

[7] Koss LG, Melamed MR. Koss's diagnostic pathology. In: Breast. Fifth edition. Lippincott Williams \& Wilkins; 2006.

[8] Jara-Lazaro AR, Tan PH. Molecular pathogenesis of progression and recurrence in breast phyllodes tumors. AJTR. 2009; 1 (1): 23-34. Available at: http://www.ajtr.org/files/AJTR811004.pdf

[9] Tan PH, Jayabaskar T, Chuah KL, Lee HY, Tan Y, Hilmy M, Hung H, Selvarajan S, Bay BH. Phyllodes Tumors of the Breast:The Role of Pathologic Parameters. American Journal of Clinical Pathology. 2005;123:529-40. Available

http://ajcp.ascpjournals.org/content/123/4/529.full.pdf

[10] Ducatman BS, Wang HH. Cytology: Diagnostic principles and clinical correlates. In: Breast. Cibas ES, Ducatman BS, editor. Saunders Elsevier; 2009.

[11] Wurdinger S, Herzog A, Fischer DR, Marx C, Rabeez G, Scheider A, Kaiser W. Differentiation of phyllodes breast tumors from fibroadenomas on MRI. AJR. 2005; 185: 1317-21. Available at: http://www.ajronline.org/content/185/5/1317.full.pdf

[12] Pinder SE, Ellis IO, Lee AHS, Elston CW. Muir's textbook of pathology. In: The breast. Levison DA, Reid R, Burt AD, Harrison DJ, Fleming S, editor. Fourteenth edition. Edward Arnold (Publishers) Ltd; 2008 